\title{
ECOPHYSIOLOGICAL INVESTIGATIONS OF UNDERSTORY EASTERN REDCEDAR IN CENTRAL MISSOURI ${ }^{1}$
}

\author{
James P. Lassoie \\ Department of Natural Resources, Cornell University, \\ Ithaca, New York 14853 USA \\ Phillip M. Dougherty \\ Weyerhaeuser Company, P.O. Box 269, \\ Wright City, Oklahoma 74766 USA \\ Peter B. Reich \\ Boyce Thompson Institute, Cornell University, \\ Ithaca, New York 14853 USA \\ Thomas M. HinCKLEY \\ College of Forest Resources, University of Washington, \\ Seattle, Washington 98195 USA \\ Clifford M. Metcalf \\ 402 Lindenwood, St. Charles, Missouri 63301 USA
}

AND

STephen J. Dina

Department of Biology, St. Louis University, St. Louis, Missouri 63103 USA

Abstract. Eastern redcedar (Juniperus virginiana) is a sun-adapted, drought-resistant pioneer species common to pastures, abandoned fields, fence rows, and calcareous rock outcrops throughout the eastern United States. However, it is also a frequent component of the understory in mature oakhickory forests in central Missouri, where light levels are typically $<10 \%$ of full sunlight during much of the growing season. This is below eastern redcedar's reported optimum for photosynthesis. The competitive survival of understory eastern redcedar under such environmental conditions was apparently due to it being an evergreen conifer in a deciduous forest. Hence, its foliage was able to maintain a positive carbon dioxide balance throughout much of the year, with maximum net photosynthetic rates occurring during periods when the overstory was leafless.

The greatest daily average net photosynthetic rates $\left(\overline{P h}_{n}\right)$ occurred during overstory leaf emergence when temperatures were moderate and light levels to the understory trees were annually the highest. Furthermore, since leaf temperatures and tree water deficits were relatively low at this time, daily gas exchange rates were not greatly limited by midday stomatal closure. After the overstory foliage had fully developed, understory light levels averaged $\approx 50-80 \%$ below levels observed in early spring. Thus, photosynthesis was severely light limited during the day, resulting in $\overline{P h}_{n}$ that were $\approx 15-45 \%$ of the springtime maxima. The greatest daily average transpiration rates $(\overline{T R})$ occurred during the summer due to the high evaporative demand. Increasing leaf temperatures and tree water deficits became more important by late summer, causing stomatal closure during some afternoons, which reduced $\overline{P h}_{n}$ and $\overline{T R}$ to $\approx 30$ and $40 \%$, respectively, of the early summer levels.

During the autumn, winter, and early spring, understory light levels were normally above the saturation point for photosynthesis. The light saturation point for an understory study tree (expressed as flux of photosynthetically active photons) was $\approx 800 \mu \mathrm{mol} \cdot \mathrm{m}^{-2} \cdot \mathrm{s}^{-1}$, less than half of that reported for open-grown eastern redcedar. This relatively lower light saturation point suggested an adjustment to shade conditions. During the autumn overstory defoliation period, light levels to understory trees progressively increased, and $\overrightarrow{P h}_{n}$ eventually reached $80 \%$ of the springtime maximum. In contrast, $T R$ only reached $\approx 25 \%$ of the summer maximum, owing to relatively low evaporative demands.

During the late autumn and winter, low leaf and soil temperatures combined to limit gas exchange severely. The major controlling factors seemed to be cold air temperatures directly inhibiting $\overline{P h}_{n}$ and cold soil temperatures indirectly producing tree water deficits due to reduced water uptake at the soil-root interface. Such conditions promoted persistent stomatal closure, resulting in $\overline{P h}_{n}$ near zero. However, a temporary warming trend during the winter caused an increase in $\overline{P h}_{n}$ to a level $\approx 30 \%$ of the springtime maximum. Higher net photosynthetic rates probably were not possible due to the effects of low soil and air temperatures on the stomatal mechanism and on the photosynthetic apparatus.

Key words: eastern redcedar; ecophysiology; Juniperus virginiana; photosynthesis; shade tolerance; understory vegetation; water relations.

${ }^{1}$ Manuscript received 20 October 1981; revised 6 December 1982; accepted 9 December 1982. 
TABlE 1. Study dates, site locations, eastern redcedar study trees, and tree and environmental factors measured at the University of Missouri Ashland Wildlife Area.

\begin{tabular}{|c|c|c|c|c|c|c|c|c|c|c|c|c|}
\hline \multirow[b]{2}{*}{ Date } & \multirow[b]{2}{*}{ Site* } & \multirow[b]{2}{*}{ Treet number } & \multicolumn{4}{|c|}{ Tree factors } & \multicolumn{6}{|c|}{ Environmental factors $\S$} \\
\hline & & & $P$ & $P h_{n}$ & $T R$ & $T_{l}$ & $R_{s}$ & $P A R$ & $T_{a}$ & $V P D$ & $T_{s}$ & $\psi_{s}$ \\
\hline June-September 1972 & A & 7 & $X$ & & & & & & & & & $X$ \\
\hline April 1974 & $A, B$ & $1,2,3,4$ & $\mathrm{X}$ & & & & $X$ & & $\mathrm{X}$ & $x$ & & $X$ \\
\hline June-September 1974 & $\mathrm{~A}, \mathrm{~B}$ & $1,2,3,4,5,6$ & $x$ & & & & $X$ & $X$ & $X$ & $X$ & $X$ & $\mathrm{X}$ \\
\hline October-November & & & & $x$ & $x$ & $X$ & & & & & & \\
\hline 1975 & A & 7 & $X$ & & & & $X$ & $X$ & $X$ & $X$ & $X$ & $X$ \\
\hline January-February & & & & $X$ & $x$ & $\mathrm{X}$ & & & & & & \\
\hline 1976 & A & 7 & $X$ & & & & $\mathrm{X}$ & $X$ & $\mathrm{X}$ & $\mathrm{X}$ & $\mathrm{X}$ & $X$ \\
\hline June-July 1976 & A & 7 & $X$ & $X$ & $X$ & $X$ & & $X$ & $\mathrm{X}$ & $X$ & $X$ & $X$ \\
\hline March-May 1977 & $\mathrm{~B}$ & 3,4 & $X$ & $X$ & $X$ & $X$ & & $X$ & $\mathrm{X}$ & $X$ & $\mathrm{X}$ & $\mathrm{X}$ \\
\hline
\end{tabular}

$* \mathrm{~A}=$ oak-hickory forest overstory dominants $\approx 20 \mathrm{~m}$ tall and $60-80 \mathrm{yr}$ old; $\mathrm{B}=$ invaded old-field overstory dominants $\approx 15 \mathrm{~m}$ tall and $35-45 \mathrm{yr}$ old.

$\dagger$ Trees $1,2,5,6$, and 7 are suppressed, understory eastern redcedar $\approx 1-2 \mathrm{~m}$ tall; trees 3 and 4 are intermediates $\approx 10 \mathrm{~m}$ tall.

$\ddagger P=$ xylem pressure potential, $P h_{n}=$ net photosynthetic rate, $T R=$ transpiration rate, $T_{l}=$ leaf temperature (see text for explanations).

$\S R_{s}=$ solar radiation, $P A R=$ photosynthetically active radiation, $T_{a}=$ air temperature, $V P D=$ vapor pressure deficit, $T_{s}=$ soil temperature, $\psi_{s}=$ soil water potential (see text for explanations).

\section{INTRODUCTION}

Eastern redcedar (Juniperus virginiana) is the most widely distributed tree-size conifer in the eastern half of the United States (Little 1971). Within its natural range, genetic races and introgressants exist, resulting in diverse phenotypes (von Rudloff 1975, Van Haverbeke and Read 1976, Flake et al. 1978). It is considered intolerant of shade (Baker 1949, Ormsbee et al. 1976) but is well adapted to a wide range of sites. In support of this characterization, Ormsbee et al. (1976) found a light optimum for photosynthesis in excess of $1750 \mu \mathrm{mol} \cdot \mathrm{m}^{-2} \cdot \mathrm{s}^{-1}$. However, this tree can also survive beneath a mature-forest overstory or within a heavy grass cover (Beilmann and Brenner 1951). In such habitats light attenuation during the summer can result in $<10 \%$ of full sunlight (i.e., $\approx 200 \mu \mathrm{mol} \cdot \mathrm{m}^{-2}$. $\mathrm{s}^{-1}$ ) reaching understory trees (Hinckley et al. 1981). Thus, photosynthesis in subordinate eastern redcedar should be severely light limited during most of the overstory growing season. The question then arises: how does eastern redcedar survive in the understory given its shade-intolerant characteristics?

The following ecophysiological study addresses this question based on an analysis of temporal variations in net photosynthesis, transpiration, and xylem pressure potential, and an examination of the environmental factors which control these processes.

\section{METHODS}

This study was conducted from June 1972 to May 1978 at the University of Missouri Ashland Wildlife Area, located $9 \mathrm{~km}$ east of the Town of Ashland. The area has been used as a research site since 1967 and is described elsewhere (e.g., Hinckley and Bruckerhoff 1975). The forest is typical of the oak-hickory forest type, with overstory tree ages of 60-80 yr. Height of the dominants averaged $18.5 \mathrm{~m}$, and the stand had a basal area of $\approx 17 \mathrm{~m}^{2} / \mathrm{ha}$. Predominant overstory tree species are white oak (Quercus alba), black oak $(Q$. velutina), and northern red oak $(Q$.rubra). Eastern redcedar is found as either a codominant or intermediate tree on old fields and southwest-facing slopes, or as a scattered, suppressed understory tree on most other sites.

Seven eastern redcedar saplings were used in this study; five were suppressed individuals growing completely beneath the overstory canopy, and two were intermediates in an invaded old field. Three trees were used in an intensive investigation of the environmental factors controlling temporal fluctuations in net photosynthetic rates and transpiration, while the others served to characterize seasonal tree water relations (Table 1). All study trees were growing on a Weller silt loam with a dense clay horizon beginning at the $50-65 \mathrm{~cm}$ depth.

Net photosynthetic rates $\left(P h_{n}\right)$ were assessed for small branches enclosed in a ventilated, thermoelectrically cooled cuvette (Dougherty et al. 1979) by measuring carbon dioxide depletion with a Beckman 315B infrared gas analyzer. Transpiration rates $(T R)$ were similarly determined using an EGG Cambridge 880 Dew Point Hygrometer and a switching system which enabled the measurement of ambient and cuvette dew points. Flow rates were maintained at $5 \mathrm{~L} / \mathrm{min}$ through the cuvette, $2 \mathrm{~L} / \mathrm{min}$ through the infrared gas analyzer, and $0.5 \mathrm{~L} / \mathrm{min}$ through the hygrometer. Gas exchange rates are expressed on an ovendry mass basis (dried at $70^{\circ} \mathrm{C}$ for $24 \mathrm{~h}$ ) due to the difficulty in determining surface area of eastern redcedar's scale-like needles.

A General Electric Lucalux 250-W, high-pressure sodium bulb (McCree 1972) housed in a Wide Lite Reflector (Model No. ID.-400ALB) was used in association with the cuvette to permit the development of light and temperature response curves for net pho- 

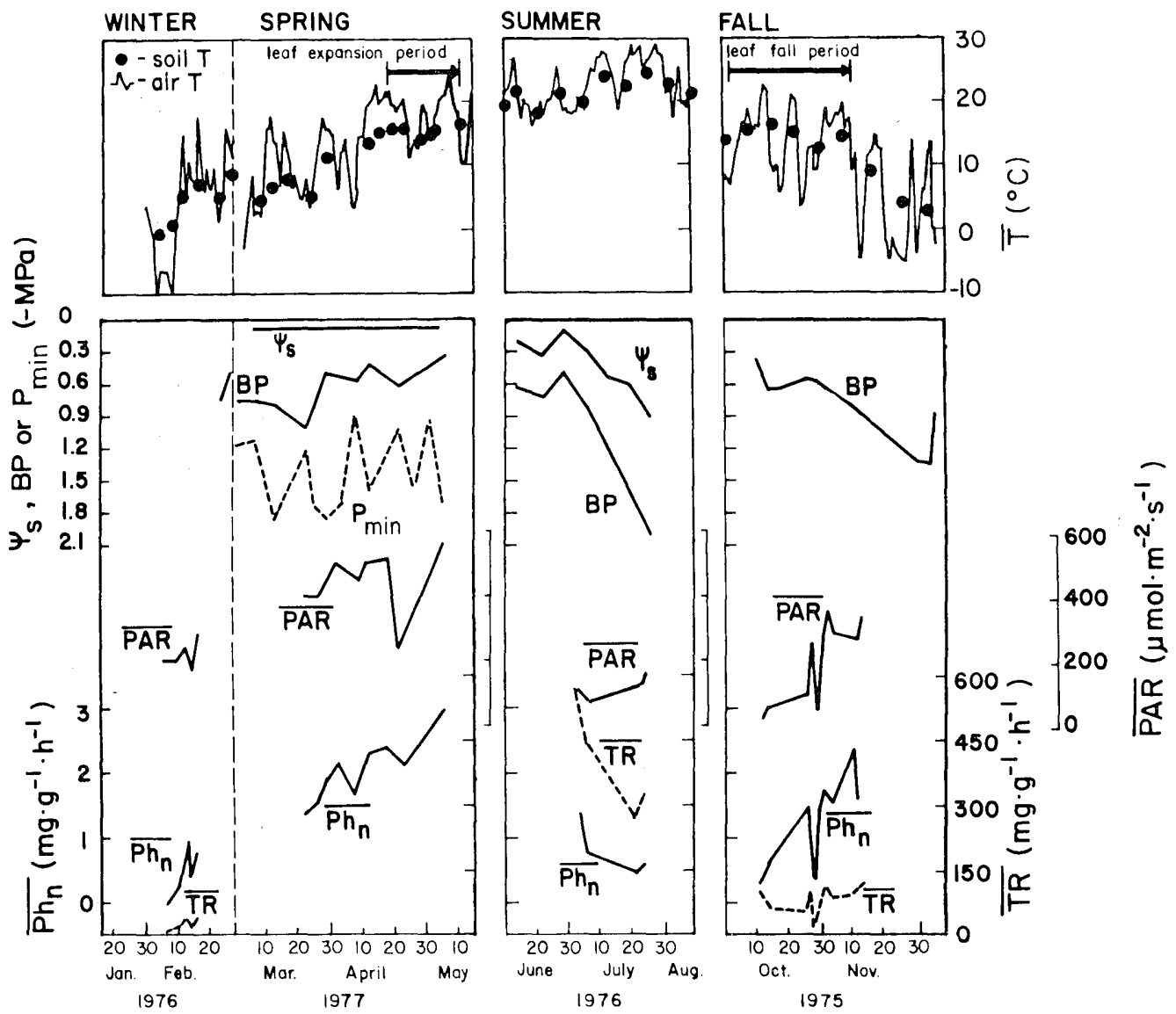

FIg. 1. Seasonal progression of hourly averages of air and soil temperatures $(\bar{T})$, photosynthetically active radiation $(\overline{P A R})$, net photosynthetic rates $\left(\overline{P h}_{n}\right)$, and transpiration rates $(\overline{T R})$. Hourly averages for $P A R, P h_{n}$, and $T R$ were determined from diurnal values greater than zero $\left(\approx 0830-1700\right.$ each day). The number of hours used for $P h_{n}$ estimates changed with the season (summer, $11.5 \mathrm{~h}$; autumn, $9.5 \mathrm{~h}$; winter, $8.0 \mathrm{~h}$; spring, $11.8 \mathrm{~h}$ ). Daily base xylem pressure potentials $(B P)$, minimum xylem pressure potentials $\left(\boldsymbol{P}_{\text {min }}\right)$, and soil water potentials $\left(\psi_{s}\right)$ are also given for some periods. The leaf fall period and time of leaf emergence are shown.

tosynthesis. This work was conducted during the early morning when air temperatures were relatively low and tree water deficits were at minimum daily levels. Except when such curves were being developed, air temperature in the cuvette tracked ambient.

Inside the cuvette, leaf temperature $\left(T_{l}\right)$ was measured by cementing a fine-wire copper-constantan thermocouple to the underside of a small branchlet. Photosynthetically active radiation $(P A R ; 400-700 \mathrm{~nm})$ was measured using two Li-Cor $190-\mathrm{S}$ quantum sensors mounted in the cuvette. Radiation values from these sensors were averaged. Environmental factors outside the cuvette were also monitored. Ambient wetand dry-bulb air temperatures were measured hourly, using an electrical diode system (Hinshaw and Fritschen 1970). Solar radiation was measured above the forest canopy, using a Kipp and Zonen solarimeter.

Branch xylem pressure potentials $(P)$ were estimated using the pressure chamber technique (Ritchie and Hinckley 1975). Contrary to the procedure normally used with conifer twigs, the phloem and bark tissues from the initial $1-3 \mathrm{~cm}$ of the cut end of the stem were not stripped prior to measurement, as this procedure was observed to give erroneous results with eastern redcedar. Extensive sampling was not always possible due to the destructive nature of this technique and the relatively small size of the study trees. This was especially true for those trees used in the intensive study of gas exchange rates.

A direct and accurate assessment of stomatal activity in eastern redcedar is difficult, due to its small, overlapping, scale-like needles, which have sunken stomata on their inside surfaces. Hence, stomatal responses to water deficits were inferred by comparing the diurnal patterns of $T R$ and $P h_{n}$ and by examining the relation between the depression of $P$ below base (i.e., predawn) xylem pressure potential $(B P$; i.e., $D P=P-B P)$ and vapor pressure deficit $(V P D)$ at any time during a day (Ritchie and Hinckley 1975).

Soil moisture was measured with a Nuclear Chicago 


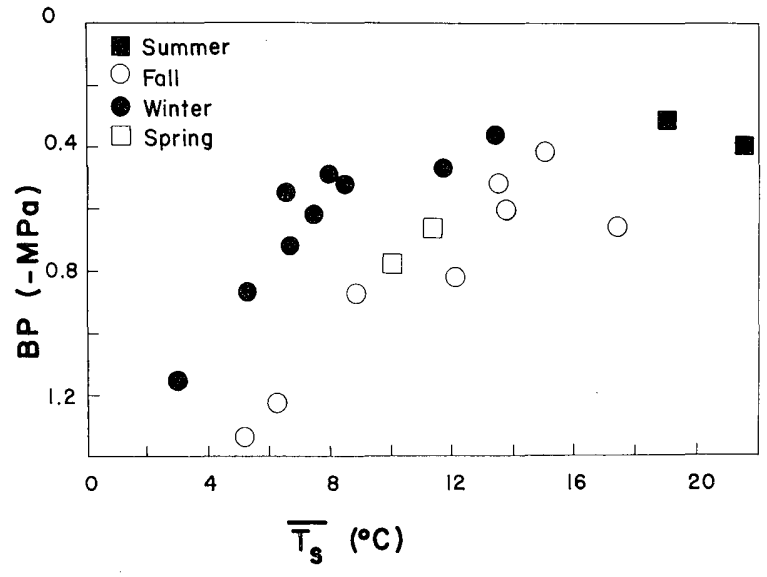

FIG. 2. The seasonal relationship between daily average soil temperature $\left(\bar{T}_{s}\right)$ and base xylem pressure potential $(B P)$ under conditions of high soil moisture (soil water potentials $>-0.1 \mathrm{MPa})$.

Model P-19 depth moisture probe and a Nuclear Chicago 2800-A scaler. Measurements were made every $15 \mathrm{~cm}$ from 15 to $105 \mathrm{~cm}$ depth and were converted to water potential values at each depth based on calibration curves developed for each tube and for each sample depth (Teskey et al. 1978). Soil temperatures $\left(T_{s}\right)$ at $15 \mathrm{~cm}$ were measured hourly with electrical diodes. Over $80 \%$ of eastern redcedar's roots in the study area were found in the top $45 \mathrm{~cm}$ of soil, due to a clay pan near this depth (R. O. Teskey, personal communication).

\section{RESUlTS}

The following results emphasize temporal variations in foliar net photosynthetic rates and those environmental and plant factors that limit $P h_{n}$ at different times of the year. Thus, the seasonal progression of physiological processes will be presented in a four-season context starting in the winter.

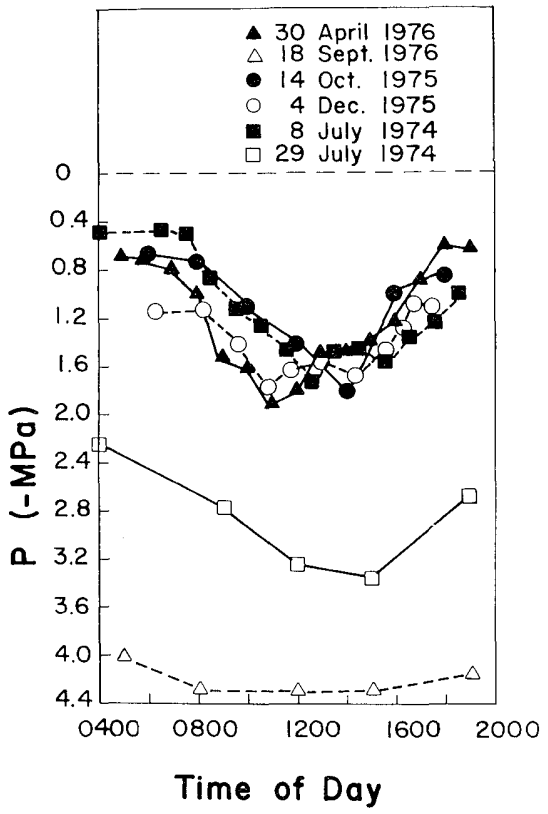

FIG. 3. Typical diurnal fluctuations in xylem pressure potentials $(P)$ for various times of the year.

\section{Winter}

The winter of 1976 was relatively mild and dry (Table 2). Although understory light levels were high during clear periods, low average daily gas exchange rates were observed (Fig. 1). Throughout the winter, soil water content was near field capacity, but $B P$ was observed to be $<-0.8 \mathrm{MPa}$ when $T_{s}$ was low (Fig. 2). Even so, daily minimum xylem pressure potentials $\left(P_{\text {min }}\right)$ did not decrease below $-2.0 \mathrm{MPa}$ (Fig. 3). Total chlorophyll content did not decrease during the winter and remained within the annual range for eastern redcedar reported by Ormsbee et al. (1976).

Air and soil temperatures were low in late January but increased during the first half of February (Fig. 1).

TABLE 2. Average daily air temperature $\left(\bar{T}_{a}\right)$ and total precipitation $(P P T)$ by month during the intensive data collection period (1975-1977) at the University of Missouri Ashland Wildlife Area compared to the 20-yr average $(\bar{x})$.

\begin{tabular}{|c|c|c|c|c|c|c|c|c|}
\hline \multirow[b]{2}{*}{ Month } & \multicolumn{4}{|c|}{$\bar{T}_{a}\left({ }^{\circ} \mathrm{C}\right)$} & \multicolumn{4}{|c|}{$P P T(\mathrm{~cm})$} \\
\hline & $\ddot{x}$ & 1975 & 1976 & 1977 & $\bar{x}$ & 1975 & 1976 & 1977 \\
\hline January & -1.6 & -0.3 & -2.0 & -10.2 & 4.7 & 8.6 & 3.1 & 3.7 \\
\hline February & 0.6 & -1.7 & 5.6 & 0.5 & 4.6 & 7.5 & 6.2 & 3.1 \\
\hline March & 6.2 & 3.0 & 8.9 & 8.5 & 7.5 & 8.2 & 12.1 & 9.2 \\
\hline April & 12.8 & 11.5 & 12.9 & 14.6 & 9.3 & 10.9 & 5.2 & 6.9 \\
\hline May & 18.1 & 18.5 & 15.2 & 20.0 & 11.9 & 10.2 & 9.4 & 10.9 \\
\hline June & 23.1 & 22.6 & 21.5 & 23.1 & 11.7 & 9.7 & 4.6 & 13.3 \\
\hline July & 25.1 & 24.8 & 25.4 & 26.3 & 8.8 & 1.4 & 0.6 & 4.1 \\
\hline August & 24.7 & 24.5 & 24.3 & 25.0 & 9.2 & 20.8 & 1.6 & 5.7 \\
\hline September & 20.5 & 17.1 & 20.2 & 21.2 & 10.9 & 14.2 & 0.9 & 16.6 \\
\hline October & 14.5 & 14.3 & 9.9 & 13.1 & 7.2 & 5.2 & 14.2 & 11.2 \\
\hline November & 6.8 & 8.5 & 1.7 & 7.3 & 5.8 & 9.1 & 3.5 & 4.6 \\
\hline December & 0.9 & 1.8 & -2.2 & -0.7 & 4.8 & 6.3 & 1.8 & 3.1 \\
\hline
\end{tabular}




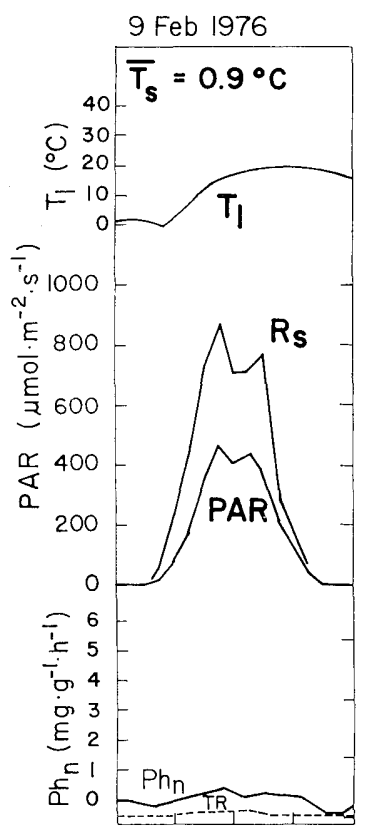

$0800 \quad 1200 \quad 1600$

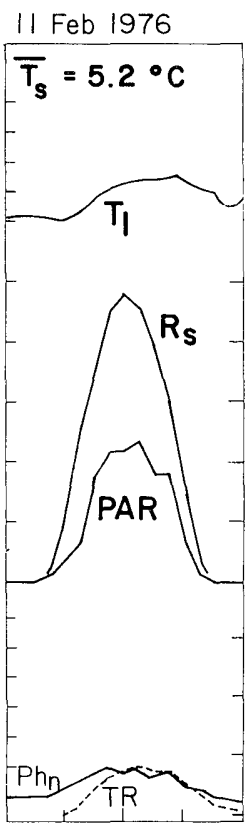

080012001600

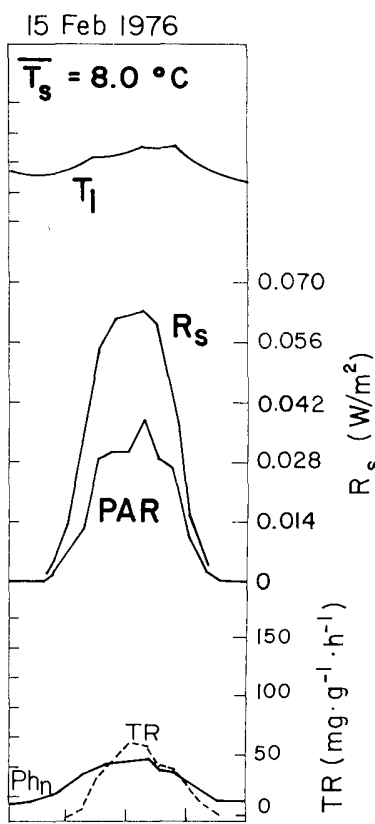

080012001600

Time of Day

FIG. 4. Daily progression of leaf temperatures $\left(T_{l}\right)$, solar radiation above the overstory canopy $\left(R_{s}\right)$, photosynthetically active radiation beneath the overstory canopy $(P A R)$, net photosynthetic rates $\left(P h_{n}\right)$, and transpiration rates $(T R)$ for three days during a warming trend in the winter of 1976. Average daylight soil temperatures $\left(\bar{T}_{s}\right)$ for each day are also given.

Closer examination of a 7-d segment of this atypical, temporary warming trend illustrates the relationship of gas exchange rates to environmental conditions during the winter (Fig. 4). This period began with snow on the ground. Atmospheric conditions were clear, and light levels above and below the overstory canopy were consistently high during the period, while average $T_{s}$ at $15 \mathrm{~cm}$ increased from $0.9^{\circ}$ to $8.0^{\circ} \mathrm{C}$, and maximum daily $T_{l}$ increased from $16.0^{\circ}$ to $24.3^{\circ}$. At the beginning of this period ( 9 February), near-freezing morning air temperatures were common, and $P h_{n}$ and $T R$ were negligible and insensitive to daily changes in $P A R$ and $T_{l}$. By the end of the 7-d period (15 February) gas exchange rates responded to diurnal changes in radiation and leaf temperature. However, maximum $P h_{n}$ observed on 15 February was only $1.0 \mathrm{mg} \cdot \mathrm{g}^{-1} \cdot \mathrm{h}^{-1}$, and it is unlikely that significant gains in carbon balance occurred during the winter. Temperature and light response curves for $P h_{n}$ were not determined for the winter period.

\section{Spring}

The spring of 1977 was atypically warm (Table 2). Beginning in early March, average daily $T_{s}$ rose from $\approx 3^{\circ}$ to over $16^{\circ}$ by early May (Fig. 1). Average daily air temperatures also increased over the $2 \frac{1}{2}$-mo period but were variable, and occasional days with temperatures below $5^{\circ}$ occurred until early April. Understory light levels increased above winter levels during the spring in response to a general decrease in cloud cover and remained high even after overstory leaf emergence began in late April (Fig. 1). These high PAR levels, however, were unique to a particular location of the cuvette which allowed for full daytime illumination during much of the spring study period (Fig. 5). Neutron probe measurements indicated that soil water potentials were $>-0.1 \mathrm{MPa}$ throughout this period. Base xylem pressure potentials, however, did not reflect the moist soil conditions until early April. By mid-May $B P$ had equilibrated to within $-0.3 \mathrm{MPa}$ with soil water potential. Minimum daily xylem pressure potentials remained $>-2.0 \mathrm{MPa}$ throughout the spring (Figs. 1 and 3).

Maximum daily $P h_{n}$ in mid-March was only $2 \mathrm{mg}$. $\mathrm{g}^{-1} \cdot \mathrm{h}^{-1}$, but by early May the maximum rate had increased to $4.5 \mathrm{mg} \cdot \mathrm{g}^{-1} \cdot \mathrm{h}^{-1}$ (Fig. 5). The highest average daily $P h_{n}\left(\approx 3.0 \mathrm{mg} \cdot \mathrm{g}^{-1} \cdot \mathrm{h}^{-1}\right)$ observed during the entire study was recorded in early May (Fig. 1). This suggests that environmental and physiological factors were more favorable for $P h_{n}$ during this period than at any other season. However, under conditions in which light and temperature were manipulated, $P h_{n}$ exceeded those recorded in early May under natural conditions by $\approx 0.5 \mathrm{mg} \cdot \mathrm{g}^{-1} \cdot \mathrm{h}^{-1}$ (Fig. 6A). This suggests that at no time during this period were environmental conditions at an optimum for photosynthesis. 

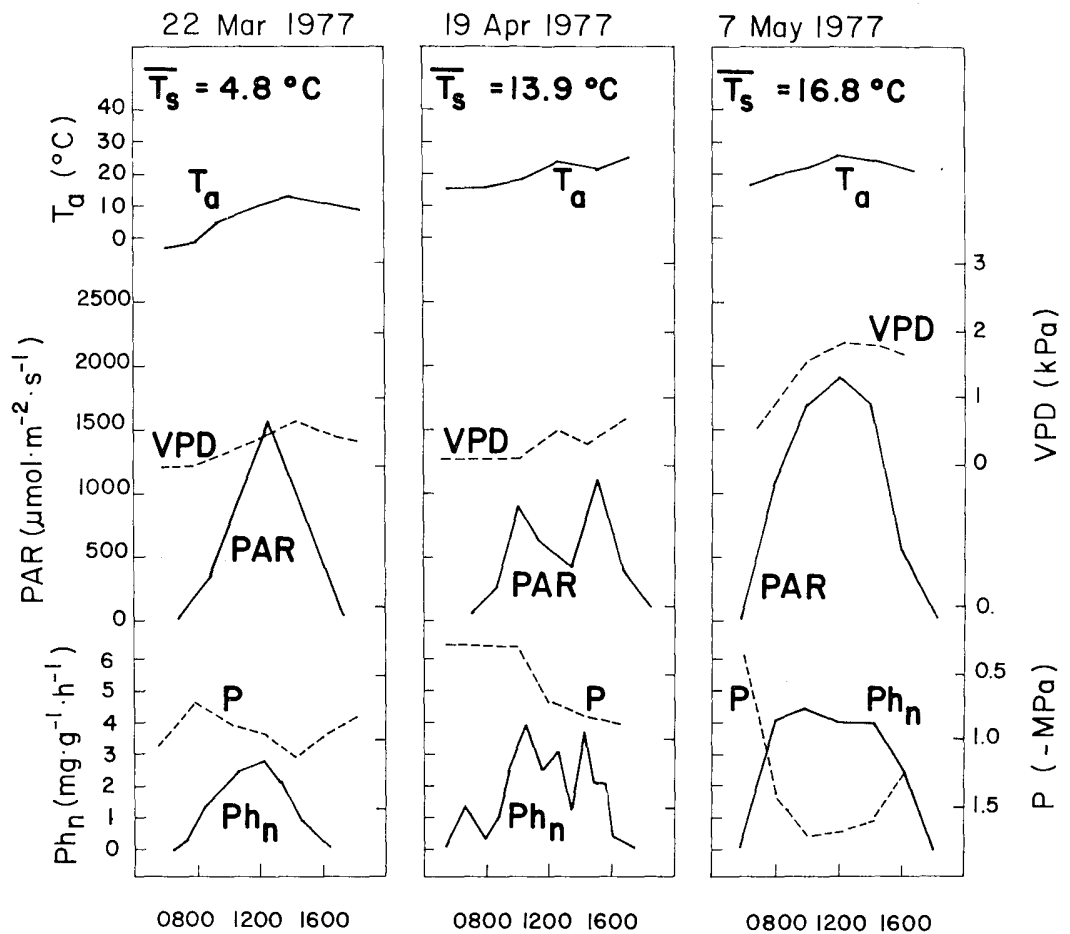

Time of Day

FIG. 5. Daily progression of air temperatures $\left(T_{a}\right)$, vapor pressure deficits $(V P D)$, photosynthetically active radiation $(P A R)$, net photosynthetic rates $\left(P h_{n}\right)$, and xylem pressure potentials $(P)$ for three days during the early spring of 1977 . Average daylight soil temperatures $\left(\bar{T}_{s}\right)$ for each day are also given.

Although daily net photosynthetic rates were highest during the spring, dark-respiration rates increased greatly as temperature increased (Fig. 6A: $P A R=0$ curve). This increase in respiration was probably associated with actual cell growth and would impact the total carbon balance during the spring.

\section{Summer}

The summer of 1976 was extremely dry (Table 2). Even on cloudless days, light levels reaching the understory eastern redcedar were relatively low due to attenuation by the fully developed overstory foliage (Fig. 1). Average hourly PAR was normally below 100 $\mu \mathrm{mol} \cdot \mathrm{m}^{-2} \cdot \mathrm{s}^{-1}$, except for temporary peaks associated with sunflecks striking the cuvette (Fig. 7). Average daily soil and air temperatures fluctuated between $\approx 16^{\circ}$ and $29^{\circ}$ but generally increased during the summer period (Fig. 1); daily $T_{l}$ maxima commonly exceeded $30^{\circ}$ (Fig. 7). Base xylem pressure potentials decreased from $\approx-0.6 \mathrm{MPa}$ in mid-June to near $-2.0 \mathrm{MPa}$ in late July in response to progressively drying soil conditions (Fig. 1). At this time, $P_{\min }$ near $-3.4 \mathrm{MPa}$ were observed (Fig. 3).

These environmental conditions resulted in both $P h_{n}$ and $T R$ remaining low throughout the summer. Net photosynthetic rates in July never exceeded $3.0 \mathrm{mg}$. $\mathrm{g}^{-1} \cdot \mathrm{h}^{-1}$, and $P h_{n}$ and $T R$ generally decreased during the month as temperatures and tree and soil water deficits increased (Figs. 1 and 7). Although $P h_{n}$ was low, there did seem to be a rapid, positive response to sunflecks reaching the cuvette position (Fig. 7). Even when $T_{l}$ and $P A R$ were optimized in late July, maximum $P h_{n}$ was only slightly $>2 \mathrm{mg} \cdot \mathrm{g}^{-1} \cdot \mathrm{h}^{-1}$ (Fig. 6B). Dark-respiration rates were less responsive to increases in $T_{l}$ in July (Fig. 6B: $P A R=0$ curve) than in early April (Fig. 6A). Thus, even though $P h_{n}$ was positive during the day, it is unlikely that understory eastern redcedar produced enough current photosynthate to support active tissue growth during the summer.

\section{Autumn}

Except for a dry period from mid-October to midNovember, the autumn of 1975 was relatively cool and wet (Table 2). Light levels at the cuvette position increased over fourfold from early October to mid-November as abscission of the overstory leaf complement occurred (Figs. 1 and 8). Average daily soil and air temperatures decreased during this period (Fig. 1) as did maximum and minimum leaf temperatures (Fig. 8). Because of the absence of precipitation, $B P$ decreased from near $-0.4 \mathrm{MPa}$ in early October to $-1.3 \mathrm{MPa}$ by late November (Fig. 1). Net photosynthetic rates responded positively to the progressive increase in $P A R$ and decrease in temperature and exceeded $5 \mathrm{mg} \cdot \mathrm{g}^{-1}$. 
$\mathrm{h}^{-1}$ in mid-November (Fig. 8). Although these rates were the highest observed during the study, they were of relatively short duration because of reduced day length. This resulted in lower daily $P h_{n}$ averages compared to the spring (Fig. 1). In contrast, $T R$ did not exhibit a major seasonal shift associated with overstory leaf abscission.

\section{Discussion}

\section{Limiting factors}

Light, temperature, soil moisture, and tree water deficits appear to interact differently to reduce $P h_{n}$ at different times of the year. Although these factors are interrelated, their apparent influence on gas exchange rates in understory eastern redcedar will be discussed separately.

Light.-Photosynthetically active radiation was probably the most important environmental factor regulating photosynthesis in understory eastern redcedar. Net photosynthesis approached light saturation at 800 $\mu \mathrm{mol} \cdot \mathrm{m}^{-2} \cdot \mathrm{s}^{-1}$ when leaf temperatures were between $5^{\circ}$ and $29^{\circ} \mathrm{C}$ (Fig. 9). This was in contrast to results from Ormsbee et al. (1976), who noted that during the summer $P h_{n}$ in open-grown eastern redcedar did not saturate, even at $1750 \mu \mathrm{mol} \cdot \mathrm{m}^{-2} \cdot \mathrm{s}^{-1}$ and $20^{\circ}$. Except for the early spring period before overstory leaf development and after autumn leaf abscission, light levels beneath the hardwood overstory were generally below $400 \mu \mathrm{mol} \cdot \mathrm{m}^{-2} \cdot \mathrm{s}^{-1}$ (Figs. 1, 4, 5, 7, and 8). At such times, $P h_{n}$ responded directly and rapidly to changes in $P A R$ received by the cuvette-enclosed foliage (Fig. 7). Hence, photosynthesis in understory eastern redcedar is probably light limited throughout the 5-mo period when fully expanded overstory leaves are present in mid-Missouri.

Leaf temperature.- As has been reported for other conifers (Larcher 1969, Lassoie 1982), light levels greatly affected the leaf temperature response curve for $P h_{n}$ in eastern redcedar (Fig. 6). Similar to the findings of Ormsbee et al. (1976), the optimum temperature for $P h_{n}$ appeared to be between $16^{\circ}$ and $22^{\circ}$ at high light levels. Although maximum rates decreased in response to summer drought, a seasonal upward shift in the temperature optimum occurred as the photosynthetic process acclimated to higher ambient temperatures (Berry and Björkman 1980).

The influence of $T_{l}$ on $P h_{n}$ became less apparent as light became more limiting. As $P A R$ decreased, the range of temperatures over which positive net photosynthetic rates were possible also decreased. Thus, at leaf temperatures in excess of $30^{\circ}$, increased respiration rates could result in negative $P h_{n}$ (i.e., net respiration) depending upon the light level (Fig. 6). Characteristic of most conifers (Lassoie 1982), the high temperature limit for positive $P h_{n}$ appeared to be $\approx 40^{\circ}$. Leaf temperatures near $35^{\circ}$ during the day were common at the study site in the summer (Fig. 7). Hence,

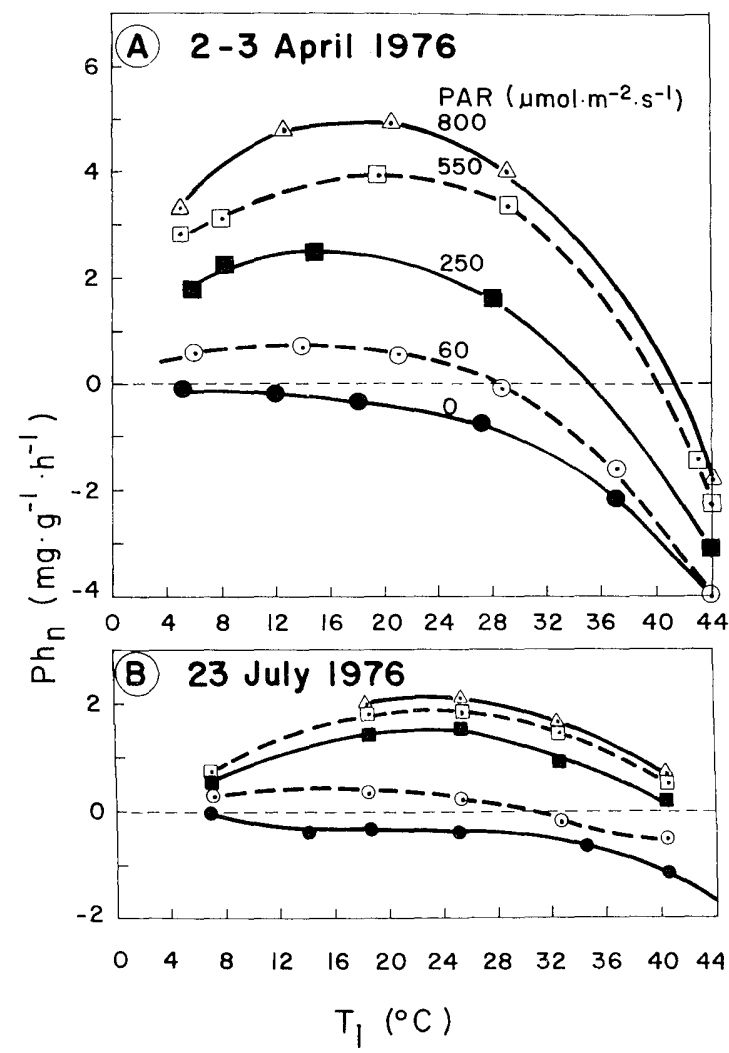

Fig. 6. Leaf temperature $\left(T_{l}\right)$ response curves for net photosynthetic rates $\left(P h_{n}\right)$ at different photosynthetically active radiation (PAR) levels during the (A) spring and (B) summer. Data points represent single measurements taken before sunrise in the field, using the controlled-environment cuvette system; curves are hand-drawn.

both light and temperature conditions may greatly limit $P h_{n}$ during much of the summer.

Low $T_{l}$ also limited $P h_{n}$, although at high light levels significant positive rates were observed at temperatures as low as $4^{\circ}$ (Fig. 6). As has been reported for other conifers (Lassoie 1982), this suggested positive net photosynthetic rates at leaf temperatures near freezing. In addition, the combination of early morning, subfreezing air temperatures, and low soil temperatures (discussed next) may further reduce $P h_{n}$ even when $T_{l}$ is optimum.

Water.-Two principal soil factors appeared to be interacting with evaporative demand to control water status in understory eastern redcedar: moisture and temperature. The daily pattern of xylem pressure potentials reflected the interaction between changing soil moisture supplies and atmosphere evaporative demands (Ritchie and Hinckley 1975, Hinckley et al. 1978) and were quite different depending upon the season (Fig. 3). Even so, daily minima (i.e., $P_{\text {min }}$ ) were not observed to be $<-1.9 \mathrm{MPa}$ during nonsummer periods (Figs. 1 and 3). Because $P h_{n}$ for eastern redcedar can 

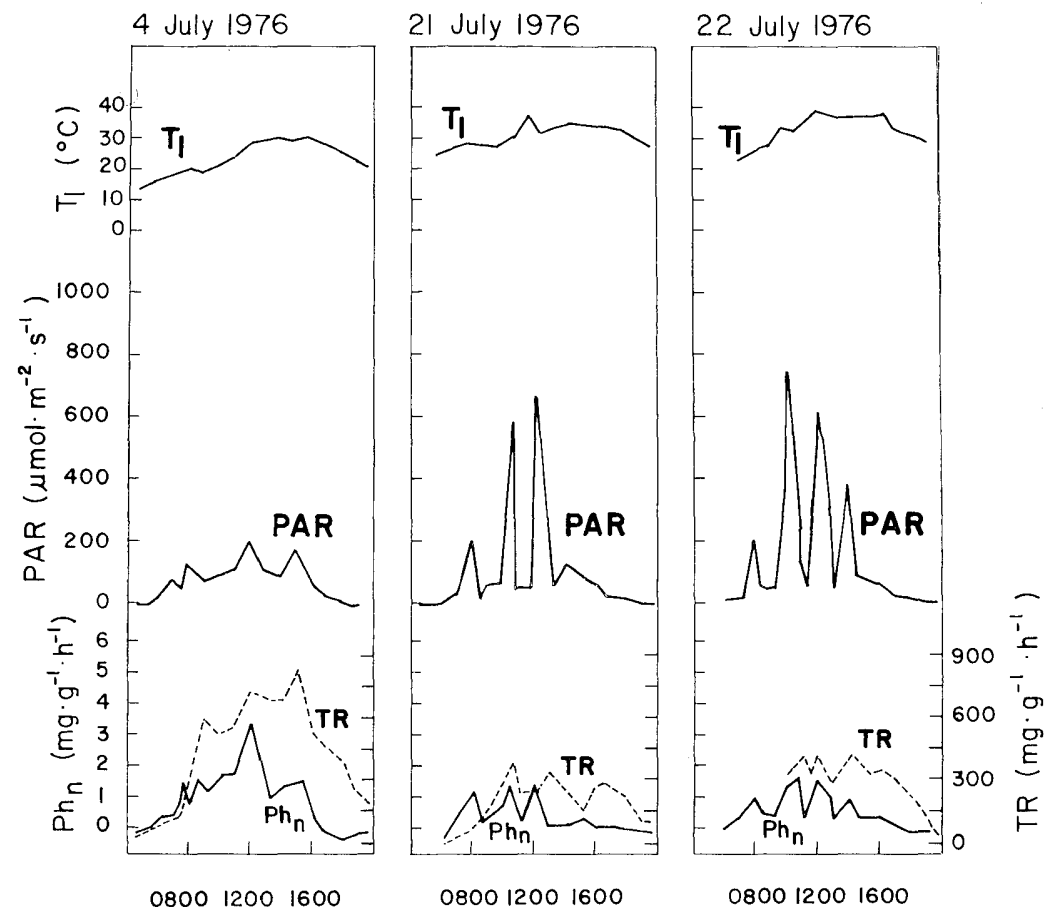

Time of Day

FIG. 7. Daily progression of leaf temperatures $\left(T_{l}\right)$, photosynthetically active radiation $(P A R)$, net photosynthetic rates $\left(P h_{n}\right)$, and transpiration rates (TR) for three days during the summer 1976.

be near maximum at xylem pressure potentials between -1.2 and $-1.8 \mathrm{MPa}$ (e.g., Fig. 1: 7 May; Ormsbee et al. 1976), it is unlikely that $P$ greatly limited gas exchange during these periods.

One exception to the above generality appeared to be related to cold soil temperatures which occurred during the winter. An examination of the relationship between daily average $T_{s}$ and $B P$ during periods of high soil moisture illustrates the indirect effect of cold soils on tree water relations and $P h_{n}$ in understory eastern redcedar (Fig. 2). As $T_{s}$ decreased below $\approx 16^{\circ}$ during the summer and autumn and below $\approx 10^{\circ}$ during the winter, $B P$ was observed to decrease from -0.34 to $-1.36 \mathrm{MPa}$. The response of $B P$ to $T_{s}$ is probably related to changes in the permeability of the root membrane, while the shift in temperature response represents a possible acclimation by roots to low soil temperatures (Turner and Jarvis 1975, Lassoie 1982). There was not a significant correlation between $T_{s}$ and $P_{\min }$, as observed by Evans (1975) with Engelmann spruce (Picea engelmanni); however, low soil temperatures did reduce water uptake, thereby reducing $B P$ (Hinckley et al. 1978).

It was assumed that during the winter, continued daytime water loss, even at low rates (Fig. 4), eventually promoted large internal water deficits and stomatal closure (Hinckley et al. 1978). The low gas exchange rates on 15 February (Fig. 4) indicated that stomata were not fully open, even following the temporary warming trend. Low soil temperatures on 15 February $\left(<8.0^{\circ}\right.$ observed at the $15-\mathrm{cm}$ depth $)$ may have limited water uptake by roots deeper in the soil. Similar delayed responses in stomatal functioning have been observed in other conifers following periods of cold temperatures (Turner and Jarvis 1975, Fahey 1979).

During the summer as the soil progressively dried, $B P$ decreased from -0.23 to $-2.22 \mathrm{MPa}$ (29 July 1974) or to $-4.25 \mathrm{MPa}$ (2 October 1976). Although the minimum $P$ reached during a day decreased as the soil dried, the differences between $P_{\min }$ and $B P$ diminished, probably as stomatal closure became more effective in reducing daily water loss (Ritchie and Hinckley 1975, Hinckley et al. 1978). Similarly, the relationship between the depression of $P$ below $B P$ (i.e., $D P$ ) and $V P D$ was different on hot summer days, when vapor pressure deficits were low, than at other times. On such days, $D P$ decreased as $V P D$ exceeded $\approx 2.4 \mathrm{kPa}$, indicating stomatal closure (Fig. 10). This was in contrast to mild days when $D P$ increased as $V P D$ increased between 0 and $\approx 2.2 \mathrm{kPa}$.

The minimum xylem pressure potential reached each day is primarily dependent on the amount of water lost relative to uptake (Ritchie and Hinckley 1975). Hence, the seasonally lowest $P_{\min }$ levels were typically observed during summer and early autumn drought pe- 

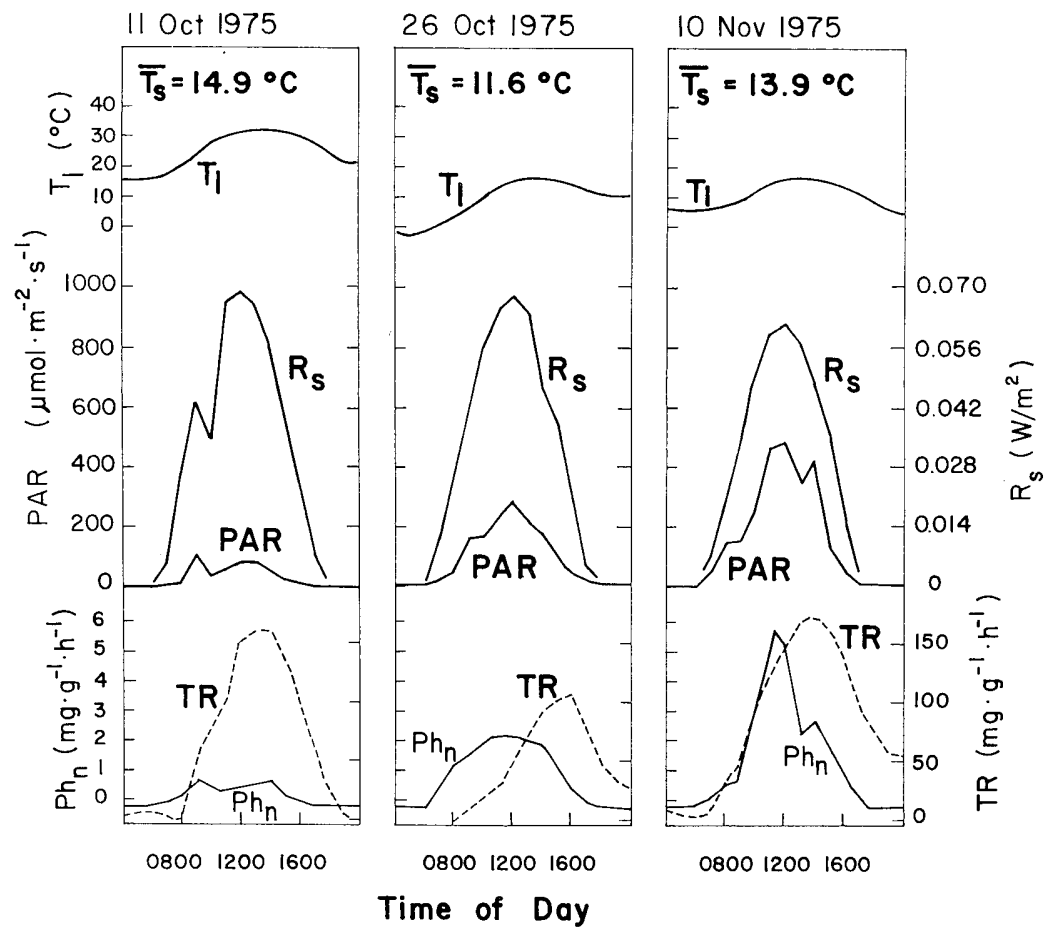

FIG. 8. Daily progression of leaf temperatures $\left(T_{l}\right)$, solar radiation above the overstory canopy $\left(R_{s}\right)$, photosynthetically active radiation beneath the overstory canopy $(P A R)$, net photosynthetic rates $\left(P h_{n}\right)$, and transpiration rates $(T R)$ for three days during the leaf abscission period in the autumn of 1975. Average daylight soil temperatures $\left(\bar{T}_{s}\right)$ for each day are also given.

riods (e.g., Fig. 3: 29 July 1974 and 18 September 1976). These values indicated that stomatal closure could have limited $P h_{n}$ during such days (Hinckley et al. 1978). However, since Ormsbee et al. (1976) have reported significant net photosynthetic rates even at xylem pressure potentials of $-3.0 \mathrm{MPa}$, it appears that internal water deficits are limiting to $P h_{n}$, only during severe drought periods.

The effect of stomatal control on gas exchange rates also can be inferred by comparing the diurnal patterns of $P h_{n}$ and $T R$. Any abrupt decrease in transpiration during periods of constant or increasing VPDs would suggest stomatal closure. On those days examined during the winter and summer, both $P h_{n}$ and $T R$ closely matched fluctuations in PAR at the needle surfaces (Figs. 4 and 7). This suggested that light was directly affecting stomatal activity and gas exchange rates. Under these conditions, $P$ thresholds for stomatal closure were usually not reached during the day. However, the general decrease in gas exchange rates as base xylem pressure potentials decreased during either the summer or winter (Figs. 1 and 2) suggested that average daily stomatal conductance decreased during summer droughts or periods of cold soil temperatures (Hinckley et al. 1978).

In the autumn, $P h_{n}$ followed the daily progression of $P A R$ and peaked prior to $T R$, which was more closely related to the diurnal pattern of $V P D$ (Fig. 8).
There was no evidence of midday stomatal closure during such periods.

\section{Ecological considerations}

Eastern redcedar is adapted to an extremely wide variety of environments: annual precipitations between 41 and $152 \mathrm{~cm}$, temperature extremes ranging from $-40^{\circ}$ to $+46^{\circ}$, elevations from 0 to $1525 \mathrm{~m}$, and

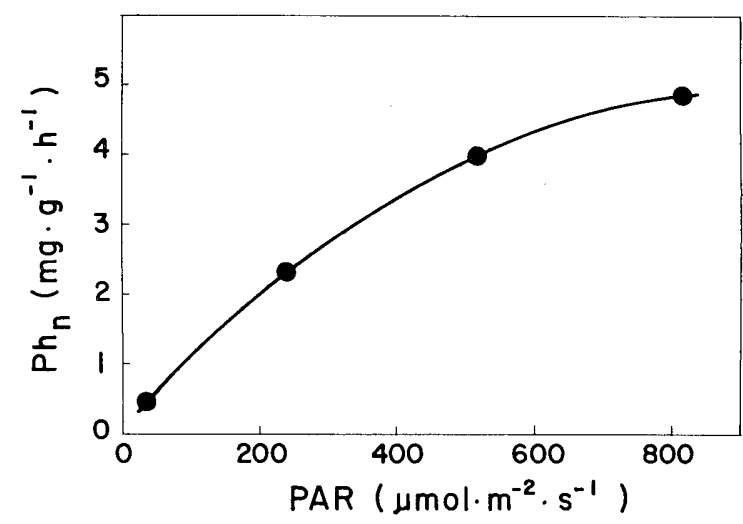

FIG. 9. Photosynthetically active radiation $(P A R)$ response curve for net photosynthetic rate $\left(P h_{n}\right)$ at $20^{\circ} \mathrm{C}$ during the early spring (3 April 1976). Data points represent single measurements taken before sunrise in the field, using the controlled-environment cuvette system; curve is hand-drawn. 


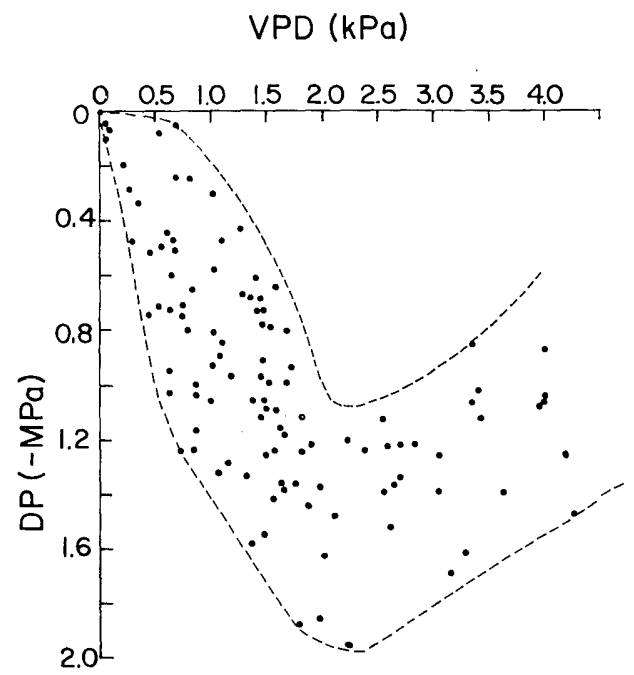

FIG. 10. Relationship between vapor pressure deficit $(V P D)$ and the hourly depression of xylem pressure potential below base xylem pressure potential $(D P)$.

growing seasons between 120 and $250 \mathrm{~d} / \mathrm{yr}$ (Van Haverbeke and Read 1976). Eastern redcedar seedlings become established most readily on areas supporting well-developed herbaceous and shrubby vegetation (Burkhardt and Tisdale 1976). Hence, this species is a vigorous pioneer and is found frequently in pastures, abandoned fields, fence rows, and on calcareous rocky outcrops (Beilmann and Brenner 1951, Ferguson et al. 1968). In Missouri it is frequently the dominant tree species on exposed south-facing slopes with thin soils (Zimmerman and Wagner 1979). Eastern redcedar has a fibrous, shallow rooting habit well adapted to shallow soils (Walker 1967), but is also known to produce rapidly growing taproots capable of absorbing water from deep soil horizons during summer droughts (Kramer 1949). These traits have led eastern redcedar to be classified as drought tolerant (Walker 1967), a classification further supported by its ability to photosynthesize at low xylem pressure potentials (Ormsbee et al. 1976).

Being a vigorous pioneer, eastern redcedar should be intolerant of shade. In fact, Baker (1949) listed it as being intolerant, and Walker (1967) noted that full sunlight was required for optimum growth rates. In further support, Ormsbee et al. (1976) reported that eastern redcedar is "excluded from mature forests because it is shade-intolerant." These authors concluded that eastern redcedar grew well in open fields because it is a sun-adapted, drought-resistant species capable of sustaining a positive net carbon dioxide balance during summer droughts and most of the winter.

However, there seems to be some confusion regarding the shade tolerance of eastern redcedar. Observations in the field suggest a reasonable tolerance for seasonal fluctuations in shading, as eastern redcedar is fairly common in the understory of midwest- ern hardwood forests (Stone and Bogley 1961). McDermott and Fletcher (1955) found that growth responses in eastern redcedar were the same at $1 / 3$ full sunlight (i.e., $\approx 660 \mu \mathrm{mol} \cdot \mathrm{m}^{-2} \cdot \mathrm{s}^{-1}$ ) as in full sunlight, but that growth was significantly reduced at $1 / 10$ full sunlight $\left(\approx 200 \mu \mathrm{mol} \cdot \mathrm{m}^{-2} \cdot \mathrm{s}^{-1}\right)$. Beilmann and Brenner (1951) considered eastern redcedar to be shade tolerant because it persisted in a subordinate position in grasslands, until favorable opportunities for rapid growth occurred. In a forested situation, such opportunities can arise from the removal of the overstory (Walker 1967). A subordinate position seems to provide winter protection by decreasing wind speeds and maintaining leaf temperatures greater than air temperatures, which can promote significant net photosynthetic rates (Ormsbee et al. 1976).

Based on the present study, understory eastern redcedar foliage seemed able to maintain positive daily carbon dioxide uptake on sunny days during much of the year. Seasonally, positive net carbon balances for such trees were maintained as they remained viable subordinate components of an oak-hickory forest in central Missouri. However, as an evergreen tree beneath a deciduous forest overstory, seasonal patterns of gas exchange rates and tree water status were different from those of overstory trees growing in this community (Hinckley et al. 1981).

Photosynthetically active radiation levels beneath the canopy on summer days were often as low as $100 \mu \mathrm{mol}$. $\mathrm{m}^{-2} \cdot \mathrm{s}^{-1}$. Thus, light was the primary limiting factor to $P h_{n}$ during the summer, with high rates being directly related to sunflecks reaching the foliage. In addition, relatively high $T_{l}$, late-summer and early-autumn tree water deficits, and incomplete stomatal opening probably further limited gas exchange. In fact, the combination of high temperatures and low light levels sometimes resulted in net photosynthetic rates near zero during a portion of the day. However, even under these severe conditions, positive daily net carbon dioxide balances of the foliage occurred even though the entire tree may have experienced a negative net balance. In contrast to the results of Ormsbee et al. (1976) with open-grown eastern redcedar, $P h_{n}$ approached saturation at light levels near $800 \mu \mathrm{mol} \cdot \mathrm{m}^{-2}$. $\mathrm{s}^{-1}$, possibly indicating adjustments in foliar morphology and/or the photosynthetic process to the low light levels beneath the canopy.

The light regime for understory eastern redcedar changed rapidly during periods when the extent of overstory foliage was changing. In the autumn, PAR levels progressively increased as defoliation of overstory hardwood trees occurred. Eventually, light intensities to understory trees were well above the saturation point for photosynthesis during most of the day. As a result, $P h_{n}$ steadily increased and eventually reached levels much higher than those observed during the summer. Decreased atmospheric evaporative demands, leaf temperatures, and soil water deficits 
during the autumn reduced water loss and the frequency of midday stomatal closure, further assisting in the maintenance of higher net photosynthetic rates.

In the spring, an opposite pattern was observed. Prior to overstory leaf expansion, cold air and soil temperatures limited $P h_{n}$ by affecting photosynthetic reactions and root water uptake, respectively. Temperatures steadily increased during the spring and were probably not limiting to $P h_{n}$ by mid-April. At such times, conditions were favorable for photosynthesis (i.e., high light, moderate temperatures, and high soil water levels), and rates were high. Thus, spring and autumn were the seasons when most of the annual carbon dioxide fixation occurred. However, conditions changed quickly as leaf expansion in the overstory progressed during the spring. Eventually, decreases in understory light levels reduced photosynthesis, while temperatures increased promoting higher transpiration rates; both conditions became more typical of summer months.

An ecological advantage of an evergreen tree is that positive net carbon dioxide balances are possible during nongrowing-season periods (Waring and Franklin 1979). However, as with other times of the year, certain environmental variables can be limiting to the photosynthetic process. Light can be quite low during overcast winter days, but this did not seem to be the primary factor limiting photosynthesis in understory eastern redcedar. Limiting conditions during the winter seemed to be associated with cold air and soil temperatures. A warming trend during the winter caused a significant increase in $P h_{n}$, though a lag in response occurred. Even though wintertime net photosynthetic rates were relatively low, they seemed to be at least sufficient to meet foliar respiration levels during this period. However, since this period was atypical, it is unlikely that positive net carbon balances exist throughout the winter.

\section{Conclusion}

This study indicated that a major amount of carbon dioxide fixation occurred in understory eastern redcedar during periods when the overstory trees were leafless and air and soil temperatures were relatively low but above freezing. During such times, maintenance respiration rates were typically low. Even during the summer when temperatures and respiration rates were high and understory light levels were low, understory eastern redcedar's light saturation point for photosynthesis was low enough to maintain a positive carbon dioxide balance for the foliage during sunny days. Positive carbon balances for foliage also seemed possible during the winter as long as soil temperatures were above freezing and light levels were high.

Eastern redcedar is a widely distributed tree species, implying that there is considerable genetic variation within this species, resulting in diverse phenotypes (Van Haverbeke and Read 1976). Given such plastic- ity, one might expect eastern redcedar to be able to adjust to a wide variety of environments. This study has helped to explain the presence of this pioneer tree species in an oak-hickory hardwood forest understory.

\section{ACKNOWLEDGMENTS}

This research was supported by funds provided by McIntire-Stennis Project 169 and by the Research Council of the Graduate School, University of Missouri, Columbia, Missouri. Contribution of the Missouri Agriculture Experiment Station, Journal Series No. 8473. Publication costs were provided by Cornell University Agricultural Experiment Station and Weyerhaeuser Company. The authors acknowledge and thank two anonymous reviewers and Dr. T. J. Fahey and Mr. D. J. Decker, Department of Natural Resources, Cornell University, Ithaca, New York, for their editorial assistance. The authors also acknowledge Mr. Douglas J. Norton, Seatuck Research Program, Laboratory of Ornithology, Cornell University, Ithaca, New York, for designing and drawing the illustrations used in this paper.

\section{Literature Cited}

Baker, F. S. 1949. A revised tolerance table. Journal of Forestry 47: 179-181.

Beilmann, A. P., and L. G. Brenner. 1951. The recent in trusion of forests in the Ozarks. Annals of the Missouri Botanical Garden 38:261-282.

Berry, J., and O. Björkman. 1980. Photosynthetic response and adaptation to temperature in higher plants. Annual Review of Plant Physiology 31:491-543.

Burkhardt, J. W., and E. W. Tisdale. 1976. Causes of juniper invasion in southwestern Idaho. Ecology 57:472-482.

Dougherty, P. M., R. O. Teskey, J. E. Phelps, and T. M. Hinckley. 1979. Net photosynthesis and early growth trends of a dominant white oak (Quercus alba L.). Plant Physiology 64:930-935.

Evans, A. K. 1975. Water relations of Engelmann spruce during snowmelt. Dissertation. Colorado State University, Fort Collins, Colorado, USA.

Fahey, T. J. 1979. The effect of night frost on the transpiration of Pinus contorta spp. latifolia. Oecologia Plantarum 14:483-490.

Ferguson, E. R., E. R. Lawson, W. R. Maple, and C. Mesauage. 1968. Managing eastern redcedar. United States Forest Service Research Paper SO-37.

Flake, R. H., L. Urbatsch, and B. L. Turner. 1978. Chemical documentation of allopatric introgression in Juniperus. Systematic Botany 3:129-144.

Hinckley, T. M., and D. M. Bruckerhoff. 1975. The effects of drought on water relations and stem shrinkage of Quercus alba. Canadian Journal of Botany 53:62-72.

Hinckley, T. M., J. P. Lassoie, and S. W. Running. 1978. Temporal and spatial variations in the water status of forest trees. Forest Science Monograph 20.

Hinckley, T. M., R. O. Teskey, F. Duhme, and H. Richter. 1981. The water relations of the hardwood forest. Pages 153-208 in T. T. Kozlowski, editor. Water deficits and plant growth. Volume 6. Academic Press, New York, New York, USA.

Hinshaw, R., and L. J. Fritschen. 1970. Diodes for temperature measurement. Journal of Applied Meteorology 9:530-532.

Kramer, P. J. 1949. Plant and soil-water relationships. McGraw-Hill, Hightstown, New Jersey, USA.

Larcher, W. 1969. The effect of environmental and physiological variables on the carbon dioxide gas exchange of trees. Photosynthetica 3:167-198.

Lassoie, J. P. 1982. Physiological activity in Douglas-fir. Pages 126-185 in R. L. Edmonds, editor. Analysis of co- 
niferous forest ecosystems in the western United States. United States International Biological Program Synthesis Series, Number 14. Hutchinson Ross, Stroudsburg, Pennsylvania, USA.

Little, E. L., Jr. 1971. Atlas of United States trees. I. Conifers and important hardwoods. United States Forest Service Miscellaneous Publication Number 1146.

McDermott, R. E., and P. W. Fletcher. 1955. Influence of light and nutrition on color and growth of redcedar seedlings. Agriculture Experiment Station Research Bulletin 587, University of Missouri, Columbia, Missouri, USA.

McCree, K. J. 1972. Test of current definitions of photosynthetically active radiation against leaf photosynthesis data. Agricultural Meteorology 10:443-453.

Ormsbee, P., F. A. Bazzaz, and W. R. Boggess. 1976. Physiological ecology of Juniperus virginiana in oldfields. Oecologia (Berlin) 23:75-82.

Ritchie, G. A., and T. M. Hinckley. 1975. The pressure chamber as an instrument for ecological research. Pages 165-254 in A. Macfadyen, editor. Advances in ecological research. Volume 9. Academic Press, New York, New York, USA.

Stone, R. N., and W. T. Bogley. 1961. The forest resource of Nebraska. United States Forest Service Release. Rocky Mountain Forest and Range Experiment Station, Fort Collins, Colorado, USA.
Teskey, R. O., J. L. Chambers, G. S. Cox, T. M. Hinckley, and J. E. Roberts. 1978. A severe drought: I. Soil-site relationships in an oak-hickory forest. Pages 316-324 in W. E. Balmer, editor. Proceedings of soil moisture-site productivity symposium. United States Forest Service, State and Private Forestry, Southeastern Area, Myrtle Beach, South Carolina, USA.

Turner, N. C., and P. G. Jarvis. 1975. Photosynthesis in Sitka spruce (Picea sitchensis [Bong.] Carr.) IV. Response to soil temperature. Journal of Applied Ecology 12:561576.

Van Haverbeke, D. F., and R. A. Read. 1976. Genetics of eastern redcedar. United States Forest Service Research Paper WO-32.

von Rudloff, E. 1975. Chemosystematic studies of the volatile oils of Juniperus horizontalis, J. scopulorum and $J$. virginiana. Phytochemistry 14:1319-1329.

Walker, L. C. 1967. Silviculture of the minor southern conifers. School of Forestry Bulletin 15, Stephen F. Austin State College, Nacogdoches, Texas, USA.

Waring, R. H., and J. F. Franklin. 1979. Evergreen coniferous forests of the Pacific Northwest. Science 204:13801386.

Zimmerman, M., and W. L. Wagner. 1979. A description of the woody vegetation of oak-hickory forests in the Northern Ozark highlands. Bulletin of the Torrey Botanical Club 106: 117-122. 